\title{
Identifikasi Scatophagus argus yang dipasarkan di Jakarta berdasarkan Analisis Morfologi dan DNA Barcoding
}

\author{
Sulistiowati* dan Hawis Madduppa \\ Departemen IImu dan Teknologi Kelautan, Fakultas Perikanan dan Ilmu Kelautan, IPB University \\ Jl. Raya Dramaga, Babakan, Dramaga, Bogor, Jawa Barat \\ Email: sulistiowati.595@gmail.com
}

\begin{abstract}
Identification Chatched Fish Landed from Muara Baru Modern Fish Market, Jakarta

Species list of economical fish landed in Muara Baru Modern Fish Market, Jakarta needs to be examined. Fish species information needs to know the species of fish being traded. However, many species are difficult to identify morphologically. The aim of this research was to identify fish based on their morphological characters and DNA barcoding. The methods of this research were morphologic, morphometric, and molecular identification with DNA barcoding using PCR. Morphological analysis results showed that fish samples have unique characteristics in the presence of spots on their bodies and fading in the abdomen. Morphometric observations were made with 19 different characters and weight measurements. The 19 fish characters observed have a standard deviation of $<1$, mean that the fish samples taken have a size that was not much different. A comparison ratio of 18 morphometric characters to total length (PT) showed variable results. Genetic analysis of the fish studied had the Max Score and Total Score was same, 1201, Query Coverage was $95 \%$, and Ident was $100 \%$. Based on morphological analysis and DNA barcoding used by fish species identified as Scatophagus argus species. Both methods were successfully carried out and the two methods complement each other to identify fish species correctly and accurately.
\end{abstract}

Keywords: DNA barcoding; morphology; Scatophagus argus

\begin{abstract}
Abstrak
Jumlah ikan ekonomis yang banyak diperjualbelikan di Pasar Muara Baru, Jakarta perlu dilakukan penelitian. Informasi spesies ikan perlu diketahui untuk mengetahui jenis ikan yang diperjualbelikan. Penelitian ini bertujuan untuk mengidentifikasi morfologi ikan dengan pendekatan studi morfometrik dan DNA barcoding. Metode yang digunakan dalam penelitian ini yaitu pengamatan morfologi dan pengukuran morfometri serta identifikasi molekuler dengan DNA barcoding menggunakan PCR. Hasil analisis morfologi menunjukkan bahwa sampel ikan memiliki karakteristik yang unik dengan adanya corak totol di seluruh tubuhnya dan memudar di bagian perut. Pengamatan morfometrik dilakukan dengan 19 karakter yang berbeda serta pengukuran berat. 19 karakter ikan yang diamati memiliki standar deviasi yang $<1$, artinya sampel ikan yang terambil memiliki ukuran yang tidak jauh berbeda. Rasio perbandingan 18 karakter morfometri terhadap panjang total (PT) menunjukkan hasil yang bervariasi. Analisis genetik dari ikan yang diteliti memiliki Max Score dan Total Score sama yaitu 1201 dengan Query Coverage 95\%, dan Ident 100\%. Berdasarkan analisis morfologi dan DNA barcoding yang digunakan spesies ikan teridenfikasi spesies Scatophagus argus. Kedua metode tersebut berhasil dilakukan dan kedua metode tersebut saling melengkapi untuk melakukan identifikasi spesies ikan secara tepat dan akurat.
\end{abstract}

Kata kunci: DNA barcoding; morfologi; Scatophagus argus 


\section{PENDAHULUAN}

Produksi perikanan Indonesia mengalami peningkatan dari tahun 20112016. Peningkatan tersebut dari 13,64 juta ton menjadi 23,51 juta ton yang berasal dari perikanan tangkap dan perikanan budidaya. Di tahun 2016, produksi perikanan tangkap lebih rendah dari perikanan budidaya, yaitu sebesar 6,04 ton dan 17,22 juta ton. Rendahnya produksi perikanan tangkap dibanding perikanan budidaya dapat disebabkan oleh berbagai faktor, seperti kondisi lingkungan laut yang semakin menurun sehingga menyebabkan turunnya stok ikan yang berpotensi ditangkap (KKP, 2018).

Pasar Muara Baru merupakan pasar ikan modern yang terletak di Penjaringan, Jakarta Utara. Pasar ini menampung berbagai jenis ikan dari yang berukuran kecil hingga besar yang berasal dari berbagai daerah. Pasar Muara Baru beroperasi selama 24 jam, namun kegiatan jual beli ramai pada pukul 00.00 04.00. Menurut Madduppa et al. (2016) ikan hasil tangkapan yang di daratkan di pasar dan diperjualbelikan selama ini tanpa identifikasi spesies ikan. Morfologi ikan yang memiliki kemiripan sulit untuk diidentifikasi spesiesnya (Prehadi et al, 2014). Hal tersebut menyebabkan pembeli ataupun pedagang terkadang mengalami kesalahan dalam mengetahui jenis ikan.

Tingginya biodiversitas ikan tangkapan yang berasal dari perairan di kepulauan Indonesia perlu adanya upaya untuk mengetahuinya spesies apa saja yang telah ditangkap dengan cara identifikasi (Madduppa, 2013). Identifikasi suatu organisme dapat dilakukan secara morfologi ataupun molekuler. Identifikasi morfologi mengacu pada kajian morfometrik. Studi morfometrik mengkaji variasi, ukuran dan bentuk dari organisme, meliputi pengukuran panjang dan analisis kerangka secara kuantitatif. DNA barcoding merupakan metode untuk mengetahui taksonomi organisme secara molekuler dengan menggunakan rantai DNA pendek untuk identifikasi suatu organisme secara cepat dan tepat. Target standar DNA barcoding untuk organisme tingkat tinggi berupa markers mitochondrial cytochrome oxidase subunit 1 atau lebih dikenal marker $\mathrm{COI}$ (Madduppa et al., 2017). DNA barcoding dikerjakan dengan menggunakan alat PCR (Polimerase Chain reaction). Analisis DNA bisa menggunakan inti sel atau mitokondria, namun penggunaaan mitokondria lebih banyak karena perkembangannya lebih cepat, ukuran kecil, sekuen dari beberapa organisme akuatik dengan pendekatan mitokondria tersedia lebih lengkap, dan rentang non-coding tidak ada (Wulansari et al., 2015).

Penelitian ini bertujuan untuk mengidentifikasi jenis ikan konsumsi dari Pasar Modern Muara baru dengan studi morfometrik dan DNA barcoding. Penelitian ini perlu dilakukan karena hingga saat masih ada kesalahan dalam identifikasi ikan terlebih pada ikan yang memiliki kesamaan morfologi sehingga membutuhkan identifikasi molekuler agar lebih akurat.

\section{METODE DAN METODE}

Penelitian dilaksanakan pada bulan Oktober 2019. Pengambilan sampel dilakukan di Pasar Muara Baru Jakarta Utara. Analisis morfometri dilakukan di lokasi pengambilan ikan, pasar Muara Baru. Analisis molekuler dilakukan di Laboratorium Biodiversitas dan Biosistematika Kelautan Fakultas Perikanan dan IImu Kelautan Institut Pertanian Bogor.

Sampel ikan sebanyak 30 ekor diamati setiap bagian tubuhnya. Karakteristik sampel diukur dengan 19 karakter sesuai penelitian Myers et al., (2013) untuk mengetahui morfometri ikan menggunakan jangka sorong. Pengukuran morfometri yang dilakukan meliputi: Panjang total (PT), Panjang standar (PS), Panjang kepala (PK), Tinggi kepala (TK), Ttinggi badan (TB), Tinggi pangkal ekor (TPE), Diameter mata (DM), Jarak antara dua mata (JAM), Lebar mata (LB), Panjang sebelum sirip dorsal (PSSD), Panjang sebelum sirip ventral (PSSV), Panjang sebelum sirip anus (PSSA), Panjang sirip dorsal (PDSD), Panjang dasar sirip ventral (PDSV), Panjang dasar sirip pektoral (PDSP), Panjang sirip ekor atas (PSEA), Panjang dasar sirip pektoral (PDSP), Panjang sirip ekor bagian tengah (PSET), panjang sirip ekor bagian bawah (PSEB), Panjang dasar sirip anus (PDSA) yang tampak pada Gambar 1. Selain morfologi ikan juga dilakukan 


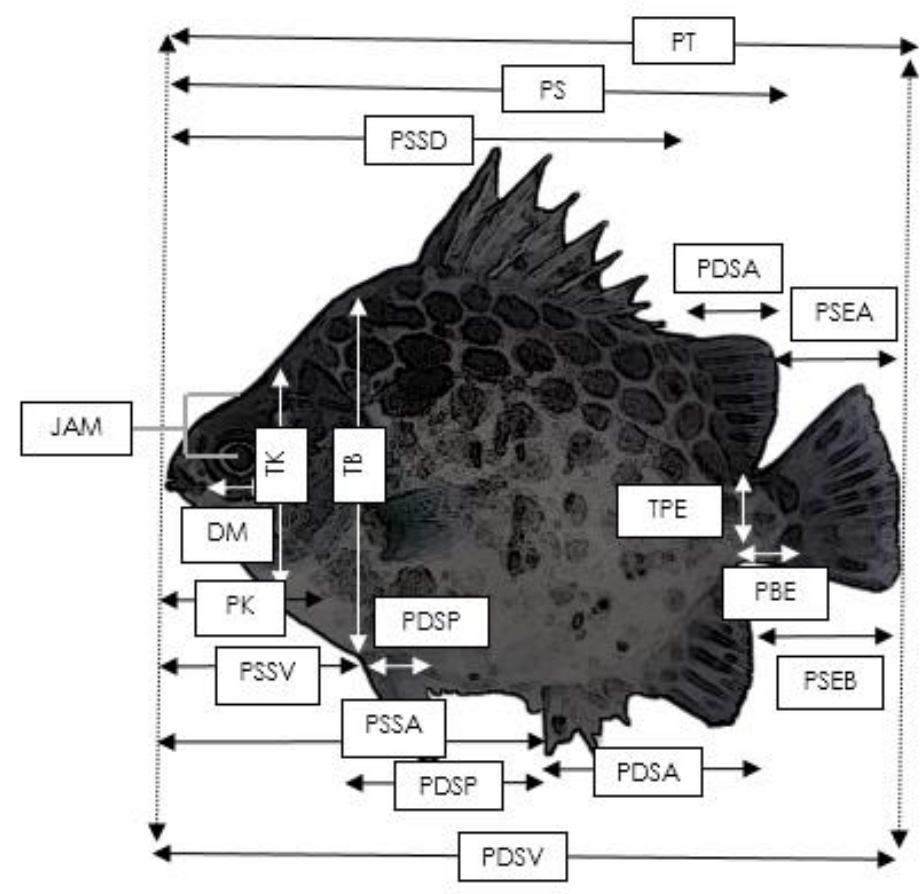

Gambar 1. Morfometri ikan

pengukuran berat dengan timbangan analitik. Sampel didokumentasikan dengan menggunakan kamera.

Ekstraksi DNA dilakukan untuk mendapatkan supernatan dari sampel yang akan dianalisis DNA-nya. Sampel berupa jaringan Scatophagus argus pada bagian ekor. Ekstraksi yang dilakukan sesuai prosedur gSYNCTM DNA Extraction Kit (Geneaid Biotech Ltd., Taiwan). Amplifikasi PCR menggunakan $\mathrm{COI}$ dengan primer berdasarkan Ward et al. (2015): FishFl (5'-TCAAACCAACCACAAAGA CATTGGCAC-3'); FishR1 (5'-TAGACTTCTGGGT GGCCA AAGAATCA-3'). Reaksi amplifikasi menggunakan volume total $25 \mu \mathrm{l}$, termasuk

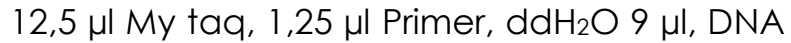
template $1 \mu \mathrm{l}$. Amplifikasi yang digunakan yaitu DIAB Master Cycler DNA Engine Thermal Cycler dengan temperatur $94^{\circ} \mathrm{C}$ selama 30 detik yang diikuti dengan 38 cycle pada saat denaturasi $\left(94^{\circ} \mathrm{C}, 30\right.$ detik), annealing $\left(50^{\circ} \mathrm{C}\right.$, 1 menit), dan extension $\left(72^{\circ} \mathrm{C}, 1\right.$ menit) serta extension akhir $\left(72^{\circ} \mathrm{C}, 1\right.$ menit). Sampel PCR discreen dengan gel agarose (120 V, 20 menit). Gel agarose yang digunakan adalah GelRedTM (Biotium R) 1\% dan diamati dibawah sinar UV transilluminator. Hasil amplifikasi dikirim ke The $1^{\text {st }}$ BASE $R$ service di Singapura untuk dianalis sequence-nya. sekuen DNA dianalisis menggunakan software MEGA 6.0. Data hasil sequence diidentifikasi untuk mengentahui spesies sampel pada Gene Bank NCBI dengan BLAST dan dibandingkan dengan referensi sekuen yang ada.

\section{HASIL DAN PEMBAHASAN}

Sampel ikan berwarna hitam keabuabuan dengan ciri khusus corak totol - totol yang tersebar ke seluruh tubuh dari punggung dan memudar pada bagian perut. Kepala spesies ikan ini tergolong unik karena berukuran kecil dan menonjol pada bagian dorsal. Operkulum berukuran sedang dengan insang yang berwarna merah gelap. Mata ikan ini terlihat kecil yang menyesuaikan dengan bagian kepala ikan yang kecil pula. Bagian dorsal spesies ini dilengkapi dengan 8 duri tajam yang memendek ke arah bagian posterior. Sirip ekor berukuran kecil, sesuai dengan tubuh ikan yang ramping seperti yang terlihat pada Gambar 2.

S. argus merupakan ikan akuatik yang penting karena memiliki nilai ekonomis yang tinggi. Nilai ekonomis yang tinggi di pasaran disebabkan karena spesies ini biasa diperjualbelikan sebagai ikan hias dan ikan 
konsumsi. Keunikan bentuk dan calm behavoir (pergerakannya pelan) menjadi alasan tersendiri bagi kolektor untuk menjadikan ikan ini sebagai ikan hias (Sivan \& Radhakrishnan, 2011). Pemanfaatan S. argus sebagai ikan konsumsi biasanya ditemukan di Asia Tenggara, ikan ini tidak hanya berkembang di wilayah Asia Tenggara, di Taiwan sudah membudidayakan jenis ikan ini. selain sebagai ikan konsumsi, ikan ini juga dimanfaatkan sebagai ikan hias. Peruntukan spesies ini sebagai ikan hias mengambil juvenil langsung dari alam, tanpa membudidayakan (Zammit \& Schembri, 2011).

Umur 1 tahun, laju pertumbuhan ikan betina diketahui 2 kali lebih cepat dari pada ikan jantan, sedangkan pada umur 2 tahun ikan jantan memiliki pertumbuhan yang lebih cepat dibanding ikan betina karena konsumsi makan harian yang tinggi (Wang et al., 2018). Spesies ini memakan beragam makanan seperti makrofita, fitoplankton, zooplankton, makrobentos, polip koral, bivalvia, anemon, alga, diatom, crustacea, polychaeta, copepoda, detritus hingga spons (Sivan \& Radhakrishnan, 2011).

S. argus merupakan ikan tropis dan subtropis yang tergolong eurihalin di alam, memiliki rentang salinitas yang tinggi (1-30\%o) sehingga yang dapat hidup di air tawar, payau, dan laut. Hal tersebut yang menyebabkan ikan ini cocok diberbagai kondisi salinatas dan terdistribusi secara luas. S. argus terdistribusi secara luas di wilayah Indo- pasifik, kepulauan melayu, Filipina, China, Australia, dan Sri lanka. Spesies ikan ini juga ditemukan di Pulau Kuril, Russia (Chen et al., 2015; Gupta, 2016; Su et al., 2019; Zammit \& Schembri, 2011).

Deskripsi S. argus dalam penelitian ini sesuai dengan yang diamati Gupta (2016), S. argus memiliki tubuh dengan kulit yang kencang. Tubuh ditutupi dengan sisik ctenoid yang berukuran kecil. Mulut berukuran kecil yang dilengkapi dengan pita-pita halus dan gigi di rahang. Gigi tidak terdapat di langitlangit mulut. Warna tubuh S. argus biru atau abu-abu kehijauan sampai coklat kehitaman atas. Perut berwarna perak dan sirip berwarna merah muda atau kekuningan berwarna abuabu coklat.

Hasil pengukuran morfometri dari 19 karakter menunjukkan bahwa sampel ikan yang diukur memiliki panjang total berkisar antara $11,4-14,6 \mathrm{~cm}$ dengan nilai rerata sebesar $13.97 \mathrm{~cm}$ dan panjang standar $11.08 \pm$ $1.48 \mathrm{~cm}$. Standar deviasi dari hasil pengukuran morfometri menunjukkan angka $<1$, artinya sampel ikan yang diamati memiliki ukuran yang tidak jauh berbeda. Adapun 19 karakteristik morfometrik sampel pada penelitian ini tercantum pada Tabel 1. Proporsi 19 karakter terhadap panjang total (PT) bervariasi. Tabel 1 diketahui bahwa panjang standar (PS) memiliki selisih yang kecil terhadap PT sehingga rationya 1. Panjang kepala (PK), Panjang sirip ekor atas (PSEA), dan Panjang sirip ekor bagian bawah (PSEB)
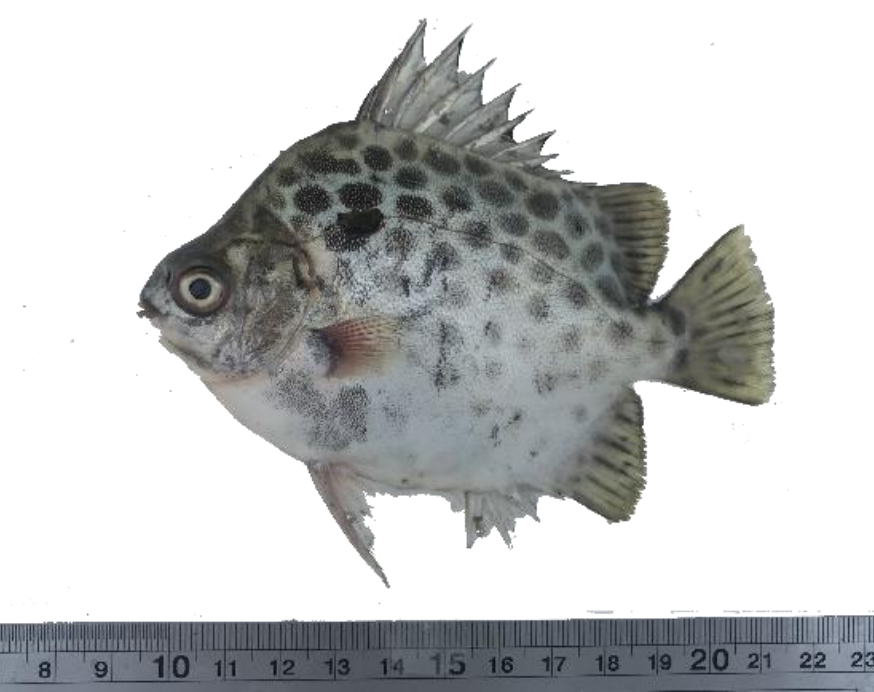

Gambar 2. Morfologi S. argus 
memiliki ratio yang sama terhadap PT yaitu 1/5. Tinggi badan (TB) dan Panjang sebelum sirip anus (PSSA) memiliki proporsi yang sama yaitu 2/5 dari panjang total. Panjang dasar sirip pektoral (PDSP) dan Panjang sirip ekor bagian tengah (PSEB) memiliki bobot ratio yang sama (1/7) terhadap PT. Diameter mata (DM) memiliki ratio yang paling kecil terhadap panjang total yaitu sebesar $1 / 14$, hal tersebut karena $S$. argus memiliki diameter mata yang kecil.

Pengukuran berat dari 30 sampel ikan dapat diketahui, ikan yang paling kecil beratnya $50 \mathrm{gr}$ sedangkan sampel ikan yang paling besar mencapai 108 gr. Rerata dari berat sampel tersebut sebesar $82,5 \mathrm{gr}$. Kesenjangan nilai berat ikan yang mencapai $50 \%$ tersebut menyebabkan nilai standar deviasinya tinggi, sebesar 14,82.

Gandhi (1998) mengungkapkan bahwa S. argus betina yang berukuran $14-14,9 \mathrm{~cm}$ dan jantan yang berukuran 12-12,9 cm sudah tergolong dewasa secara seksual. Penelitian ini diketahui bahwa panjang total (PT) rerata S. argus jantan dan betina yaitu 13,97 $\pm 1,41$ $\mathrm{cm}$, sehingga dapat disimpulkan bahwa semua sampel ikan yang ditangkap sudah dewasa secara seksual. Penelitian yang dilakukan Gupta (2016) S. argus yang dibudidayakan selama 6 bulan pada bak yang berukuran $250 \mathrm{~m}^{2}$ dengan densitas 1 ekor/m² diperoleh hasil bahwa pada juvenil dengan berat 0,41 g menjadi 10,32 gr setelah dibudidayakan. Berat ikan pada penelitian ini yang paling kecil yaitu $50 \mathrm{gr}$ dan yang paling besar mencapai $108 \mathrm{gr}$. Hal tersebut dapat disimpulkan bahwa diperkirakan umur S. argus lebih dari 6 bulan karena beratnya lebih dari 10,32 gr. Cai et al. (2010) pada penelitiannya menyebutkan bahwa baik ikan jantan maupun ikan betina melakukan reproduksi pada umur minimum 1 tahun, jadi dapat disimpulkan bahwa semua ikan yang didapat berumur lebih dari 1 tahun karena dilihat dari panjang total (PT). Selain itu, berdasarkan berat yang 10,32 gr maka dapat diduga bahwa semua ikan yang dijadikan sampel pada penelitian ini tergolong ikan dewasa.

Tabel 1. Morfometri S. Argus

\begin{tabular}{cllcc}
\hline No. & Kode & \multicolumn{1}{c}{ Karakteristik } & Ukuran Rerata $(\mathrm{cm})$ & Ratio \\
\hline 1 & PT & Panjang total & $13,97 \pm 1,41$ & 1 \\
2 & PS & Panjang standar & $11,08 \pm 1,48$ & $1 / 5$ \\
3 & PK & Panjang kepala & $3,48 \pm 0,26$ & $1 / 2$ \\
4 & TK & Tinggi kepala & $4,01 \pm 0,69$ & $2 / 5$ \\
5 & TB & Tinggi badan & $7,17 \pm 0,55$ & $1 / 8$ \\
6 & TPE & Tinggi pangkal ekor & $1,39 \pm 0,18$ & $1 / 14$ \\
7 & DM & Diameter mata & $0,99 \pm 0,10$ & $1 / 10$ \\
8 & JAM & Jarak antara dua mata & $1,94 \pm 0,14$ & $1 / 8$ \\
9 & LB & Lebar mata & $1,71 \pm 0,18$ & $2 / 7$ \\
10 & PSSD & Panjang sirip dorsal & $5,31 \pm 0,39$ & $1 / 3$ \\
11 & PSSV & Panjang dasar sirip ventral & $4,41 \pm 0,47$ & $2 / 5$ \\
12 & PSSA & Panjang sebelum sirip anus & $7,34 \pm 0,56$ & $2 / 3$ \\
13 & PDSD & Panjang sirip dorsal & $6,43 \pm 0,97$ & $1 / 4$ \\
14 & PDSV & Panjang dasar sirip ventral & $3,28 \pm 0,36$ & $1 / 7$ \\
15 & PDSP & Panjang dasar sirip & $1,97 \pm 0,21$ & $1 / 5$ \\
16 & PSEA & Pektoral & & $1 / 7$ \\
17 & PSET & Panjang sirip ekor atas & $2,63 \pm 0,26$ & $1 / 5$ \\
18 & PSEB & tengah sirip ekor bagian & $2,09 \pm 0,19$ & $2 / 9$ \\
19 & PDSA & banjang sirip ekor bagian & $2,53 \pm 0,26$ & \\
\hline
\end{tabular}




\section{Identifikasi Molekuler}

Kontrol negatif yang digunakan yaitu PCR mix tanpa primer. Kontrol negatif ini berfungsi sebagai pembanding terhadap sampel. Hasil elektroforesis diketahui bahwa jumlah base pair S. argus sudah dengan sesuai primer yang digunakan sekitar $600 \mathrm{bp}$, artinya hasil elektroforesis sampel berhasil yang tampak pada Gambar 3. Adapun urutan basa nitrogen hasil sekuen terlihat pada Gambar 4 berikut, sedangkan hasil BLAST pada NCBI tercantum pada Tabel 2. Hasil eleketroforesis sampel didapatkan data bahwa sampel ikan tersebut memiliki jumlah 679 bp, penelitian ini sesuai dengan penelitian yang dilakukan oleh Prehandi et al. (2014) yang menggunkan metode DNA barcoding dengan primer pada PCR (Polymerase Chain Reaction) untuk proses amplifikasinya dengan jumlah basa pair 600-700 dengan Cytochrome Oxidase I (COI) locus mitochondrial.

Berdasarkan analisis DNA barcoding gen COl terhadap sampel yang dibandingkan dengan dengan database GenBank NCBI didapatkan tingkat kemiripan tertinggi dengan spesies Scatopagus argus dengan Max Score dan Total Score sama yaitu 1201, Query Coverage 95\%, dan Ident 100\%. Menurut Triandiza \& Maddupa (2018) sekuen bank gen yang paling mirip dicirikan dengan nilai Max Score dan Total Score sama, Query Coverage mendekati 100\%, dan Ident mendekati $100 \%$ pada setiap data base seperti terlihat pada Tabel 2. Hasil BLAST dapat disimpulkan bahwa sampel ikan yang diteliti spesies Scatophagus argus. Spesies ini termasuk dalam famili Scatophagidae, ordo Perciformes. Ikan ini merupakan spesies

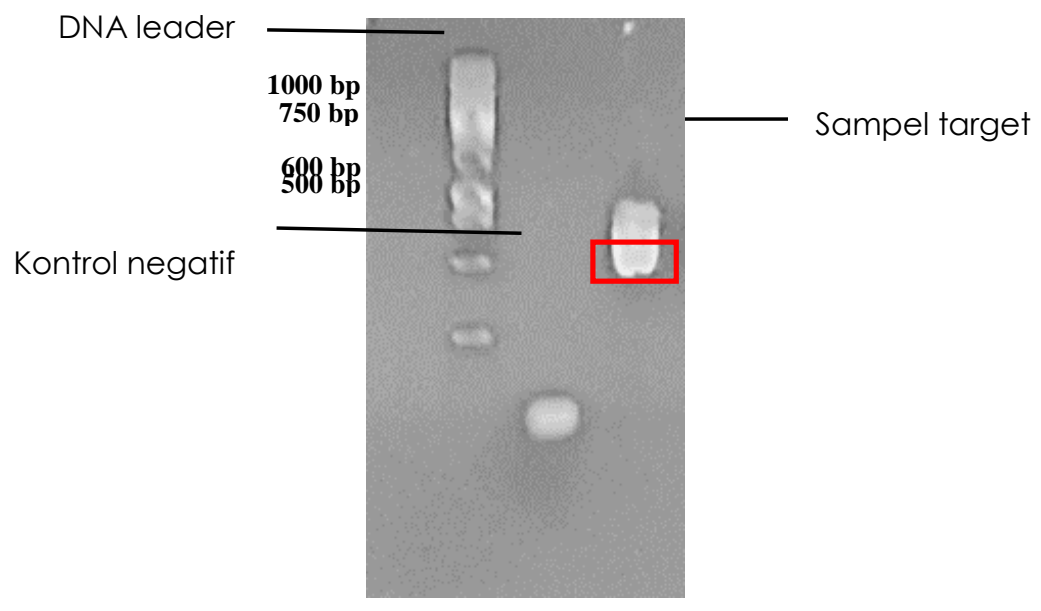

Gambar 3. Hasil Elektroforesis

\begin{abstract}
TCTGTATTCGGTGCCTGAGCAGGGATAGTTGGGACAGCCTTAAGCCTCCTTATCCGTGCTGAACTAAGCCAACCA GGGGCTCTCCTTGGAGACGACCAGATCTATAATGTGATCGTAACGGCACATGCCTTCGTAATAATTTTCTTTATAG TTATGCCAGTAATAATTGGAGGGTTTGGAAATTGACTGGTTCCCCTAATGATCGGGGCACCGGATATAGCATTCC CCCGGATAAATAACATAAGCTTCTGACTCCTTCCCCCTTCTTTCCTTCTCCTTCTAGCTTCCTCTGGCGTAGAAGCCG GGGCTGGAACAGGATGAACAGTCTACCCCCCTCTCGCTGGTAATCTAGCACATGCGGGAGCCTCCGTAGACCTAA CCATCTTCTCACTTCACTTGGCAGGGATTTCTTCAATCCTTGGGGCTATTAACTTCATCACCACTATTATTAATATAA AATCCCCTGCTGCTTCCCAATATCAAACTCCTCTATTCGTCTGAGCAGTCCTAATTACTGCTGTCTTACTACTCCTCT CTCTACCTGTTCTTGCTGCTGGCATCACAATACTTCTTACAGATCGAAACCTGAACACCTCTTTCTTTGATCCTGCAG GAGGAGGAGACCCAATTCTTTACCAACATCTATTCTGATTCTTTGGGCACCCAGAAGTCTAAAA
\end{abstract}

Gambar 4. Hasil Sekuensing DNA 
Tabel 2. Hasil Blast Sekuen DNA

\begin{tabular}{|c|c|c|c|c|c|c|}
\hline No. & Deskripsi & $\begin{array}{l}\text { Skor } \\
\text { Max }\end{array}$ & $\begin{array}{l}\text { Skor } \\
\text { Total }\end{array}$ & $\begin{array}{l}\text { Query } \\
\text { Cover }\end{array}$ & $\begin{array}{l}\text { Persentase } \\
\text { identifikasi }\end{array}$ & Aksesi \\
\hline 1. & $\begin{array}{l}\text { Scatophagus argus } \\
\text { cytochrome c oxidase } \\
\text { subunit I (COI) gene, } \\
\text { partial cds; mitochondrial }\end{array}$ & 1201 & 1201 & $95 \%$ & $100.00 \%$ & KU234319.1 \\
\hline 2. & $\begin{array}{l}\text { Scatophagus argus } \\
\text { voucher Q193A } \\
\text { cytochrome oxidase } \\
\text { subunit I (COI) gene, } \\
\text { partial cds; mitochondrial }\end{array}$ & 1195 & 1195 & $99 \%$ & $98,81 \%$ & KY634866.1 \\
\hline 3. & $\begin{array}{l}\text { Scatophagus argus } \\
\text { voucher KUT } 1829 \\
\text { cytochrome oxidase } \\
\text { subunit } 1 \text { (COI) gene, } \\
\text { partial cds; mitochondrial }\end{array}$ & 1186 & 1186 & $95 \%$ & $99.85 \%$ & KF930378.1 \\
\hline
\end{tabular}

populer ikan aquarium di dunia karena penampakan yang menarik, memiliki ketahanan yang tiggi, pertumbuhannya lambat, dan ikan yang tidak agresif (Gupta, 2016).

\section{KESIMPULAN}

Berdasarkan analisis morfologi dan DNA barcoding yang digunakan spesies ikan yang teridenfikasi yaitu scatophagus argus. Metode identifikasi morfologi dan molekuler tersebut saling melengkapi untuk melakukan identifikasi spesies ikan. identifikasi molekuler berguna untuk mengkonfirmasi kebenaran idenfitikasi morfologi.

\section{DAFTAR PUSTAKA}

Cai, Z., Wang, Y., Hu, J., Zhang, J., \& Lin, Y. 2010. Reproductive biology of Scatophagus argus and Artificial Induction of Spawning. J. Tropic Oceanograp. 29(5):180-185. doi: 10.3969/j.issn.1009-5470.2010.05. 029

Chen, H.P., Deng, S.P., Dai, M.L., Zhu, C.H., \& Li, G.L. 2015. Molecular cloning, characterization, and expression profiles of androgen receptors in spotted scat (Scatophagus argus). Genet. Mol. Res. 15 (2):1-12. doi: 10.4238/gmr.15027838.
Gandhi, V. Studies on the ecology and biology of butterfish scatophagus argus in Mandapam coastal region. Ph.D. Thesis.

Gupta, S. 2016. An Overview on Morphology, Biology, and Culture of Spotted Scat (Linnaeus 1766). Fish. Sci. \& Aquacul. 24 (2):203-212. doi : 10.1080/23308249.2015. 1119800

KKP. 2018. Produktivitas Perikanan Indonesia. Dalam acara Evaluasi Pelaksanaan Anggaran Tahun 2017.

Madduppa, H., Taurusman, A A., Subhan, B., Anggraini, N. P., Fadillah, R. \& Tarman, K. 2017. Short Communication: DNA Barcoding Reveals Vulnerable and Not Evaluated Spesies of Sea Cucumbers (Holothuroidea and Stichopodidae) from Kepulauan Seribu Reefs, Indonesia. Biodiversitas. 18(3):893-898. doi: 10.13057/ biodiv/d180305

Madduppa, H., Ayuningtyas, R.U., Subhan, B., Arafat, D., \& Prehadi. 2016. Exploited but Unevaluated: DNA Barcoding Reveals Skates and Stingrays (Chordata, Chondrichthyes) Species landed in The Indonesian Fish market. IImu Kelautan. 21 (2):77-84. doi: 10.14710/ik.ijms.21.2.7784.

Madduppa, H., Subhan, B., Suparyani, E., Siregar, A.M., Arafat, D., Tarigan, S.A., Alimuddin, Khairudi, D., Rahmawati, F., \& Bramandito, A. 2013. Dynamics of fish 
diversity across an environmental gradient in the Seribu Islands reefs off Jakarta. Biodiversitas. 14(1):17-24. doi: 10.13057/bio $\mathrm{div} / \mathrm{d} 140103$.

Myers, P., Espinosa, R. et al. 2013. http:// animaldiversity. ummz. umich. Edu/ collec tions/contributors/Grzimek_fish/Clupeifor mes/Chirocentrus_dorab/.[accessed date : 06 Desember 2019].

Prehadi, Sembiring, A., Kurniasih, E.M., Rahmad, Arafat, D., Subhan, B., Madduppa, H. 2015. DNA barcoding and phylogenetic reconstruction of shark species landed in Muncar fisheries landing site in comparison with Southern Java fishing port. Biodiversitas, 16(1):55-61. doi: 10.13057/biodiv/d160107

Sivan, G. \& Radhakrishnan, C.K.. 2011. Food, Feeding Habits and Biochemical Composition of Scatophagus argus. Turkish J. Fish. Aqutic Sci. 11:603-608. doi: 10.4194/1303-2712-v11_4_14

Su, M., Duan, Z., Shi, H. \& Zhang, J.. 2019. The effects of salinity on reproductive development and egg and larvae survival in the spotted scat Scatophagus argus under controlled conditions. Aquacul. Res., 50(7):11-13. doi: 10.1111/are.14056

Triandiza, T. \& Madduppa, H. 2018. Aplikasi Analisa Morfologi dan DNA barcoding pada Penentuan jenis Kepiting Porcelain (Pisidia sp.) yang Berasal dari Pulau Tunda,
Banten. J. Sumberdaya Akuatik Indopasifik. 2(2):81-90. doi: 51-1-193-1-10201901191

Wang, M., Deng, S.P., Chen, H.P., Jiang, D.N., Tian, C.X., Yang, W., Wu, T.L., Zhu, C.H., Zhang, Y. \& Li, G.L., 2018. Phoenixin participated in regulation of food intake and growth in spotted scat, Scatophagus argus. Comparative Biochem. Physiolog. 226:36-44. doi: 10.1016/j.cbpb.2018.07.0 07

Ward, R.D., Winiger, V., Higa, K.K., Kahn, J.B., Kandel, E.R., Balsam, P.D., \& Simpson, E.H. 2015. The impact of motivation on cognitive performance in an animal model of the negative and cognitive symptoms of schizophrenia. Beharioral Neurosci. 129(3):292-299. doi: 10.1037/bne 0000051.

Wulansari, Nurilmala, N.M., \& Nurjananh. 2015. Deteksi Ikan Tuna dan Produk Olahannya berbasis protein dan DNA Barcoding. J. Pengolah. Hasil Perikan. Indo., 18(2):119127. doi: 10.17844/jphpi.2015.18.2.119

Zammit, E. \& Schembri, P.J. 2011 . An overlooked and unexpected Introduction? Occurrence of the spotted scat Scatophagus argus (Linnaeus, 1766) (Osteichthyes: Scatophagidae) in the Maltese Islands. Aqua. Invation 6(1):S79-S83. doi: 10.3391/ai.2011.6.51.018 